\title{
HUBUNGAN PENGETAHUAN PERAWAT DENGAN KELENGKAPAN DOKUMENTASI ASUHAN KEPERAWATAN DI RSUD dr.SOEKARDJO KOTA TASIKMALAYA
}

\author{
Nurul Nuryani', Dwi Dahlia Susanti \\ ${ }^{1}$ Staf RS Tasik Medika Citratama, ${ }^{2}$ Dosen Program Studi D III PIKES Poltekkes kemenkes Tasikmalaya, \\ Email : nurulnuryani_47@yahoo.com,ummu.marshayza@gmail.com
}

\begin{abstract}
The implementation of medical record documentation is conducted by various professionals of health workers and one of them is a nurse. Based on preliminary study with a sample of 10 medical record documents of the operating room in 2013 taken randomly, only 4 (40\%) documents are filled completely and 60\% documents are incompletely filled. This research aims to recognize The Relationship between Nurses's knowledge and the Completeness of documentation of nursing care of Operating Room in RSUD dr. Soekardjo Tasikmalaya quarterly period 1 of 2013. The methodology of this research used is analytical survey by using cross sectional approach. The population of research are the nurses and medical record of operating room documentation. The sample was taken by total sampling technique for a nurse and simple random sampling for document. The analytical univariate used a distributional frequency and the analytical bivariate uses chi square test. The results showed that 35.55\% have good knowledge, 33.33\% have sufficient knowledge and $31.11 \%$ have less knowledge. The completeness of documentation of nursing care of Operating Room is 29,5\% whereas the amount of incompleteness is 70,5\%. So the result showed that there is a relationship between Nurses's knowledge and the completeness of documentation of nursing care with the result $P=0,001(P<0,05)$. From this result we suggests that nurses need documentation's training to improve the quality of documentation.
\end{abstract}

Keywords : completteness of documentation, nurses's knowlegde

\begin{abstract}
Abstrak
Pelaksanaan pendokumentasian rekam medis dilaksanakan oleh berbagai profesi tenaga kesehatan salah satunya adalah perawat. Berdasarkan studi pendahuluan dengan sampel 10 dokumen rekam medis ruang bedah tahun 2013 yang diambil secara acak hanya 40\% yang diisi secara lengkap dan 60\% tidak lengkap. Penelitian ini bertujuan untuk mengetahui hubungan pengetahuan perawat dengan kelengkapan pengisian dokumentasi asuhan keperawatan ruang bedah di RSUD dr.Soekardjo Kota Tasikmalaya Periode Triwulan I Tahun 2013. Metode penelitian yang digunakan adalah survey analitik dengan menggunakan pendekatan "cross sectional”. Metode pengumpulan data dengan menggunakan kuesioner dan lembar observasi.Sampel diambil dengan teknik total sampling untuk perawat yaitu sebanyak 45 orang dan simple random sampling untuk dokumen didapatkan sebanyak 271 dokumen. Analisis univariat menggunakan distribusi frekuensi dan analisis bivariat menggunakan uji chi square. Hasil penelitian menunjukkan bahwa 35,55\% memiliki pengetahuan baik 33,33\% memiliki pengetahuan cukup dan 31,11\% memiliki pengetahuan kurang. Kelengkapan pengisian dokumentasi asuhan keperawatan ruang bedah sebanyak 29,5\% sedangkan ketidaklengkapannya sebanyak 70,5\%. Berdasarkan hasil uji statistik didapatkan bahwa ada hubungan antara pengetahuan perawat dengan kelengkapan pengisian dokumentasi asuhan keperawatan dengan hasil $\mathrm{P}=0,001(\mathrm{P}<0,05)$. Saran dalam penelitian ini adalah perlu dilakukan pelatihan, pendidikan, dan sosialisasi mengenai hal tersebut.
\end{abstract}

Kata kunci : Kelengkapan dokumen, Pengetahuan Perawat 


\section{PENDAHULUAN}

Rekam medis dikatakan lengkap jika terisinya data identifikasi pasien, pelaporan penting, otentikasi serta menggunakan tata cara pendokumentasian yang baik (Hatta, 2008). Apabila pengisian rekam medis tidak lengkap maka akan mengakibatkan informasi yang ada dalam rekam medis menjadi tidak tepat, tidak akurat, dan tidak sah atau legal. Selain itu, ketidaklengkapan pengisian dokumen rekam medis dapat mempengaruhi terhadap kegunaan rekam medis seperti administrasi, hukum, keuangan, penelitian, pendidikan dan dokumentasi.

Faktor-faktor yang berpengaruh dalam pelaksanaan pendokumentasian adalah pengetahuan, usia dan motivasi (Setiyarini, 2004). Wawan dan Dewi (2011) mendeskripsikan bahwa pengetahuan merupakan hasil "tahu" dan ini terjadi setelah orang mengadakan penginderaan terhadap suatu objek tertentu. Pengetahuan pelaksanaan pendokumentasian harus dimiliki oleh berbagai profesi tenaga kesehatan salah satunya adalah perawat. Seorang perawat mempunyai peran dalam melaksanakan pendokumentasian asuhan keperawatan dalam rekam medis (Damayanti, 2013).

Seorang perawat harus mampu melaksanakan dokumentasi asuhan keperawatan dalam rekam medis dengan lengkap, jelas, akurat dan dapat dipahami oleh orang lain. Namun, dalam pelaksanaannya pengisian dokumentasi asuhan keperawatan dalam rekam medis oleh tenaga perawat pada dasarnya masih memiliki permasalahan, yaitu masih rendahnya tingkat pemahaman terhadap pendokumentasian asuhan keperawatan. Hal ini sesuai dengan hasil penelitian Mastini (2013) tentang hubungan pengetahuan, sikap dan beban kerja dengan kelengkapan pendokumentasian asuhan keperawatan irna di RSUP Sanglah Denpasar diperolehnya responden dengan pengetahuan kurang dengan kelengkapan pendokumentasian tidak sesuai sebanyak $86,4 \%$.

Mengingat pentingnya rekam medis untuk rumah sakit, maka perlu adanya pengendalian terhadap pengisian rekam medis yang dilakukan secara berkala untuk menjaga kualitas isi rekam medis sehingga informasi yang dihasilkan menjadi lebih lengkap, jelas dan akurat serta berkesinambungan. Mahyunita (2012) menyatakan bahwa rekam medis yang lengkap dapat memenuhi standar untuk mendapatkan predikat akreditasi. Selain itu, rekam medis yang lengkap dapat dijadikan sebagai perlindungan hukum bagi pasien, rumah sakit maupun dokter dan tenaga kesehatan lainnya, sebagai dasar dalam perhitungan biaya pembayaran pelayanan medis, alat komunikasi antara dokter dan tenaga kesehatan lainnya yang ikut andil dalam proses pemberian pelayanan serta dapat dijadikan sebagai bahan yang berguna untuk analisa, penelitian dan evaluasi terhadap kualitas pelayanan yang telah diberikan kepada pasien.

Data diatas didukung oleh survei pendahuluan yang dilakukan di RSUD dr.Soekardjo pada tanggal 10 Februari 2014. Peneliti memperoleh data dari bagian seksi rekam medis pada bagian analizing, diketahui presentase ketidaklengkapan dokumentasi asuhan keperawatan yang tertinggi terdapat di ruang bedah.

Tabel 1. Data Ketidaklengkapan Dokumentasi Asuhan Keperawatan

\begin{tabular}{clll}
\hline No. & \multicolumn{1}{r}{ Ruang } & Jumlah & Presentase \\
\hline 1. & Bedah Umum & 47 & $5,57 \%$ \\
\hline 2. & Saraf & 0 & $0 \%$ \\
\hline 3. & Kandungan & 0 & $0 \%$ \\
\hline 4. & Dalam & 0 & $0 \%$ \\
\hline 5. & Anak & 0 & $0 \%$ \\
\hline 6. & Umum & 0 & $0 \%$ \\
\hline
\end{tabular}

Peneliti mengambil sampel dari 10 dokumen rekam medis ruang bedah tahun 2013 yang diambil secara acak, hanya empat dokumen (40\%) yang dokumentasi asuhan keperawatannya diisi secara lengkap dan enam dokumen (60\%) diisi tidak lengkap. Berkaitan dengan latar belakang tersebut penulis tertarik untuk mengambil judul penelitian tentang "Hubungan Pengetahuan Perawat Dengan Kelengkapan Pengisian Dokumentasi Asuhan Keperawatan Ruang Bedah di RSUD dr.Soekardjo Kota Tasikmalaya Periode Triwulan I Tahun 2013.

\section{METODE}

Penelitian ini menggunakan pendekatan "cross sectional" yaitu suatu penelitian untuk mempelajari dinamika korelasi antara faktor-faktor resiko dengan efek, dengan cara pendekatan, observasi atau pengumpulan data sekaligus pada suatu saat (point time approach) (Notoatmodjo, 2012)

Populasi merupakan keseluruhan objek penelitian atau objek yang diteliti (Notoatmodjo, 2012). Populasi penelitian ini adalah perawat yang bertugas di ruang bedah sebanyak 45 perawat dan dokumentasi 
asuhan keperawatan ruang bedah dengan jumlah 843 dokumen triwulan I tahun 2013.

Teknik pengambilan sampel untuk perawat dalam penelitian ini menggunakan teknik total sampling, maka dari itu peneliti mengambil sampel dari seluruh perawat yang bertugas di ruang bedah yaitu sebanyak 45 orang. Sedangkan teknik pengambilan sampel untuk dokumen rekam medisnya menggunakan simple random samplingdengan menggunakan angka acak (random number) didapatkan jumlah sampel untuk dokumen adalah sebanyak 271 buah.

Instrumen yang digunakan dalam penelitian ini adalah kuesioner dan lembar observasi. Kuesioner yang digunakan dalam penelitian ini adalah kuesioner yang dibuat sendiri oleh peneliti dengan menggunakan dari berbagai teori. Kuesioner ini digunakan untuk mengukur tingkat pengetahuan perawat ruang bedah di RSUD dr.Soekardjo. Dalam mengobservasi kelengkapan dokumentasi asuhan keperawatan periode triwulan I tahun 2013, peneliti menggunakan pedoman lembar observasi. Hasil uji validitas diperoleh nilai 0,859 dan uji reabilitas 0,911 sehingga kuesioner yang digunakan telah valid dan realiabel

\section{HASIL}

\section{Pengetahuan Perawat Ruang Bedah di RSUD dr.Soekardjo Kota Tasikmalaya}

Pengetahuan perawat ruang bedah di RSUD dr.Soekardjo Kota Tasikmalaya dalam penelitian ini dikategorikan dalam 3 (tiga) kategori yaitu baik, cukup dan kurang. Dari hasil penelitian dapat disajikan dalam tabel sebagai berikut :

Tabel 2. Pengetahuan Perawat Ruang Bedah tentang Dokumentasi Asuhan Keperawatan

\begin{tabular}{clll}
\hline No. & $\begin{array}{c}\text { Kategori } \\
\text { Pengetahuan }\end{array}$ & Jumlah & Persentase \\
\hline 1. & Baik & 16 & 35,55 \\
\hline 2. & Cukup & 15 & 33,33 \\
\hline 3. & Kurang & 14 & 31,11 \\
\hline Jumlah & 45 & 100 \\
\hline
\end{tabular}

Tabel 1 Data diatas menunjukkan bahwa perawat ruang bedah di RSUD dr. Soekardjo Kota Tasikmalaya memiliki pengetahuan yang hampir sebanding antara perawat yang memiliki pengetahuan baik, cukup dan kurang. Data tersebut juga menunjukkan bahwa perawat yang memiliki pengetahuan baik, cukup dan kurang itu memiliki jumlah presentase dengan selisih yang berdekatan.

2. Kelengkapan Pengisian Dokumentasi Asuhan Keperawatan Ruang Bedah Periode Triwulan I Tahun 2013

Berdasarkan data yang diperoleh dari hasil penelitian kelengkapan dokumentasi asuhan keperawatan ruang bedah dengan jumlah dokumen yang diteliti sebanyak 271 dapat disajikan pada tabel berikut:

Tabel 3. Kelengkapan Pengisian Dokumentasi Asuhan Keperawatan

\begin{tabular}{clll}
\hline No & $\begin{array}{c}\text { Kelengkapan } \\
\text { dokumen }\end{array}$ & Jumlah & Persentase \\
\hline 1 & Lengkap & 80 & 29,5 \\
\hline 2 & Tidak Lengkap & 191 & 70,5 \\
\hline Total & & 271 & 100 \\
\hline
\end{tabular}

Tabel 3 dari data diatas menunjukkan bahwa sebagian besar dokumentasi asuhan keperawatan ruang bedah periode triwulan I di RSUD dr.Soekardjo Kota Tasikmalaya diisi secara tidak lengkap dengan jumlah presentase (70,5\%). Dapat disimpulkan bahwa ketidaklengkapan pengisian dokumentasi asuhan keperawatan lebih banyak dibanding dengan kelengkapannya

3. Hubungan Pengetahuan Perawat dengan Kelengkapan Pengisian Dokumentasi Asuhan Keperawatan Ruang Bedah Periode Triwulan I Tahun 2013

Analisis hubungan yang digunakan yaitu analisis bivariat dengan menggunakan uji statistik chi square $\left(\mathrm{x}^{2}\right)$ dengan tingkat kemaknaan $\mathrm{P}$ d" 0,05 . Pengetahuan Perawat sebagai variabel bebas dan kelengkapan pengisian dokumentasi asuhan keperawatan sebagai variabel terikat. Berdasarkan hasil analisis uji statistik $C h i$ square didapatkan bahwa ada hubungan antara pengetahuan perawat dengan kelengkapan pengisian dokumentasi asuhan keperawatan dengan hasil $\mathrm{P}=0,001(\mathrm{P}<0,05)$.

\section{PEMBAHASAN}

Menurut Ardika (2012) kelengkapan pendokumentasian asuhan keperawatan dipengaruhi oleh 
berbagai macam faktor seperti latar belakang pendidikan, lama masa kerja, pengetahuan, keterampilan, motivasi dan psikologis. Hal tersebut didukung oleh pernyataan Setiyarini (2004) dalam penelitiannya yang mengemukakan bahwa salah satu faktor yang berpengaruh terhadap pelaksanaan pendokumentasian adalah pengetahuan.

Pengetahuan perawat menentukan tindakan perawat dalam memberikan pelayanan kepada pasien, sehingga tindakan perawat yang dilandasi oleh pengetahuan akan memberikan pelayanan yang lebih baik dibandingkan dengan perawat yang melakukan tindakannya tanpa didasari oleh pengetahuan. Pengetahuan perawat juga sangat berperngaruh terhadap kelengkapan pengisian dokumentasi asuhan keperawatan. Hasil penelitian menunjukkan bahwa pengetahuan perawat ruang bedah RSUD dr.Soekardjo Kota Tasikmalaya hampir setengahnya memiliki pengetahuan yang baik yaitu berjumlah 16 perawat.

Pengetahuan perawat sangat berpengaruh terhadap kelengkapan pengisian dokumentasi asuhan keperawatan. Hal ini sesuai dengan hasil penelitian diketahui bahwa dari 271 dokumen yang menjadi sampel sebagian besar dokumentasi asuhan keperawatan ruang bedah periode triwulan I di RSUD dr.Soekardjo Kota Tasikmalaya diisi secara tidak lengkap.

Seorang perawat harus mengisi dokumentasi asuhan keperawatan secara lengkap dan jelas setelah pasien menerima pelayanan. Hal ini sesuai dengan Permenkes No: 269/MENKES/PER/III/2008 pasal 2 ayat 1 yang menyebutkan bahwa rekam medis harus dibuat secara lengkap dan jelas. Rekam medis yang lengkap memuat informasi yang berkesinambungan, sehingga dengan adanya kesinambungan informasi tersebut maka setiap pasien yang datang berobat, dokter dan petugas kesehatan lainnya akan memperoleh informasi yang lengkap tentang riwayat penyakit terdahulu secara komprehensif (Shofari, 2002). Selain itu, dokumentasi asuhan keperawatan mempunyai banyak manfaat dilihat dari berbagai aspek seperti aspek hukum, kualitas pelayanan, komunikasi, keuangan, pendidikan, penelitian dan akreditasi.

Rekam medis yang tidak lengkap akan berdampak terhadap kegunaan rekam medis seperti administrasi, legal, keuangan, pendidikan, penelitian dan dokumentasi. Selain itu, ketidaklengkapan rekam medis akan menghasilkan informasi yang tidak tepat dan bersifat legal. Maka dari itu, setiap tenaga kesehatan yang memberikan pelayanan terhadap pasien harus mengisi rekam medis secara lengkap untuk menghindari hal-hal yang tidak diinginkan.

Notoatmodjo (2010) mengemukakan bahwa pengetahuan merupakan faktor yang sangat penting untuk menentukan tindakan seseorang, sehingga perilaku yang didasari pengetahuan akan lebih bertahan lama dibandingkan yang tidak didasari oleh pengetahuan, artinya semakin tinggi pengetahuan seseorang diharapkan semakin baik pula perilaku yang ditunjukannya.

Hal ini terbukti dari hasil penelitian bahwa perawat yang memiliki pengetahuan baik lebih banyak mengisi formulir dokumentasi asuhan keperawatan secara lengkap yaitu berjumlah 35 dokumen dibandingkan dengan perawat yang memiliki pengetahuan cukup berjumlah 33 dokumen dan perawat yang memiliki pengetahuan yang kurang mengisi dokumentasi asuhan keperawatan berjumlah 12 dokumen. Sedangkan perawat dengan kriteria pengetahuan baik mempunyai nilai ketidaklengkapan 62 dokumen, perawat dengan kriteria pengetahuan yang cukup mempunyai nilai ketidaklengkapan sebanyak 57 dokumen serta perawat yang memiliki kriteria pengetahuan yang kurang mempunyai nilai ketidaklengkapan sebanyak 72 dokumen. Dapat disimpulkan dari data tersebut bahwa perawat yang memiliki pengetahuan yang kurang cenderung mempunyai nilai ketidaklengkapan yang tinggi.

Berdasarkan hasil penelitian yang telah dilakukan uji statistik Chi square, diketahui bahwa terdapat hubungan pengetahuan perawat dengan kelengkapan pengisian dokumentasi asuhan keperawatan. Ini sesuai dengan penelitian sebelumnya yang dilakukan oleh Ardika (2012) diRSUP Dr. Kariadi Semarang dan penelitian Pribadi (2009) di RSUD Kelet Provinsi Jawa Tengah Jepara yaitu adanya hubungan tingkat pengetahuan perawat dengan kelenkapan pengisian dokumentasi asuhan keperawatan.

\section{SIMPULAN}

Berdasarkan hasil penelitian tentang Hubungan Pengetahuan Perawat dengan Kelengkapan Pengisian Dokumentasi Asuhan Keperawatan Ruang Bedah di RSUD dr.Soekardjo Kota Tasikmalaya Periode Triwulan I Tahun 2013, diperoleh kesimpulan sebagai berikut: 
1. Pengetahuan perawat ruang bedah di RSUD dr.Soekardjo Kota Tasikmalaya adalah dari 45 perawat yang memiliki pengetahuan baik berjumlah 16 orang $(35,55 \%)$. Berbeda sedikit dengan perawat yang memiliki tingkat pengetahuan cukup berjumlah 15 orang $(33,33 \%)$ dan perawat yang memiliki pengetahuan kurang berjumlah 14 orang $(31,11 \%)$.

2. Kelengkapan pengisian dokumentasi asuhan keperawatan ruang bedah periode triwulan I tahun 2013 adalah dari 271 dokumen yang dijadikan sampel oleh peneliti didapatkan kelengkapan pengisian dokumentasi asuhan keperawatan ruang bedah mencapai 80 dokumen (29,5\%), sedangkan ketidaklengkapan pengisian dokumentasi asuhan keperawatan ruang bedah yaitu 191 dokumen $(70,5 \%)$.

3. Dari hasil uji hubungan antara pengetahuan perawat dengan kelengkapan pengisian dokumentasi asuhan keperawatan diketahui bahwa adanya hubungan pengetahuan perawat dengan kelengkapan pengisian dokumentasi asuhan keperawatan dengan nilai $\mathrm{P}=0,001(\mathrm{P}<$ $0,05)$.

\section{DAFTAR PUSTAKA}

Ardika, R.G. (2012). Hubungan Antara Pengetahuan Perawat Tentang Rekam Medis Dengan Kelengkapan Pengisian Catatan Keperawatan. Semarang: Fakultas Kedokteran UNDIP

Arikunto, S. (2006). Prosedur Penelitian Suatu Pendekatan Praktik. Jakarta: Rineka Cipta

Arikunto, S. (2009). Prosedur Penelitian Suatu Pendekatan Praktik Revisi VI. Jakarta: Rineka Cipta

Arikunto, S. (2010). Prosedur Penelitian Suatu Pendekatan Praktik. Jakarta: Rineka Cipta

Damayanti, D. (2013). Buku Pintar Perawat Profesional Teori \& Praktik Asuhan Keperawatan. Yogyakarta: Mantra Books

Depkes, RI. (2006). Pedoman Penyelenggaraan dan Prosedur Rekam Medis Rumah Sakit di Indonesia Revisi II. Jakarta: Direktorat Jenderal Bina Pelayanan Medik
Hatta, G.R. (2008). Pedoman Manajemen Informasi Kesehatan di Sarana Pelayanan Kesehatan. Jakarta: UI Press

Kemenkes Kesehatan Republik Indonesia. (2011). Pedoman Penyelenggaraan Rekam Medis di Indonesia. Jakarta : KEMENKES

Mastini, I G. A. A. P. (2013). Hubungan Pengetahuan, Sikap dan Beban Kerja Dengan Kelengkapan Pendokumentasian Asuhan Keperawatan Irna di RSUP Sanglah. Denpasar: Fakultas Ilmu Kesehatan Masyarakat Universitas Udayana

Notoatmodjo, S. (2005). Metodologi Penelitian Kesehatan. Jakarta: Rineka Cipta

Notoatmodjo, S. (2007). Kesehatan Masyarakat : Ilmu dan Seni.. Jakarta: Rineka Cipta

Notoatmodjo, S. (2010). Kesehatan Masyarakat : Ilmu dan Seni.. Jakarta: Rineka Cipta

Notoatmodjo, S. (2012). Metodologi Penelitian Kesehatan. Jakarta: Rineka Cipta

Permenkes No. 269/MENKES/PER/III/2008 Tentang Penyelenggaraan Rekam Medis.

Pribadi, A. (2009). Analisis Pengaruh Faktor Pengetahuan, Motivasi dan Persepsi Perawat Tentang Supervisi Kepala Ruang Terhadap Pelaksanaan Dokumentasi Asuhan Keperawatan di Ruang Rawat Inap RSUD Kelet Provinsi Jawa Tengah di Jepara. Semarang:UNDIP

Setiyarini, S. (2004). Motivasi dan Disiplin Kerja Karyawan Untuk Meningkatkan Produktivitas dan Produksi. Jakarta:LSIUP

Sugiyono. (2008). Statistika Untuk Penelitian. Bandung : CV Alfabeta

Undang-Undang Republik Indonesia Nomor 36 Tahun 2009 Tentang Kesehatan

Undang-Undang Nomor 29 Tahun 2004 Tentang Praktik Kedokteran

Wawan, Adan M. Dewi.(2011). Teori dan Pengukuran Pengetahuan, Sikap, Dan Perilaku Manusia. Yogyakarta: Nuha Medika

Zaidin, A. H. (2009). Dasar-dasar Dokumentasi Keperawatan. Jakarta : EGC 